\title{
The Importance of Integrating Digital Marketing within the Sales Strategy of Luxury Brands
}

\author{
Zaif Alexandra \\ Transilvania University of Brasov, Romania \\ andra zaif@yahoo.com \\ Cerchia Alina Elena \\ Valahia University of Targoviste, Romania \\ alina cerchia@yahoo.com
}

\begin{abstract}
In the age of digital technology, companies around the world have to adapt their strategies to the new requirements and expectations of their consumers. The Internet has revolutionized traditional means of marketing, being a key factor in globalization. A market sector with hundreds of years of tradition, such as that of luxury brands, is facing the necessity to introduced new,innovative strategies into their marketing plans. The purpose of this paper is to identify the ways in which luxury brands can adopt digital marketing strategies, highlighting the benefits that could be gained ,despite some incompatibilities mentioned in previous literature studies. Thus, we intend to contribute to the clarification of certain aspects present in published literature regarding luxury brands, their perceived value and their image, determining the influences of digital marketing on the aformentioned aspects,as well as consumers consequential behaviour.
\end{abstract}

Keywords: digital marketing, social media, luxury brands

\section{Introduction}

Over the past decades, the consumption and marketing of luxury brand products have sparked great interest and generated numerous debates in both the academic,and bussiness environment,due to its complex,multidimensional nature. The interest in its research has been increasing, in the actual context of luxury market globalization .A recent study shows that,despite a global economic downturn after 2009, the luxury market continued to grow, predicting that in 2014-2019 period, it will see a 35\% increase over the previous benchmark (Bain \& Company, 2014).This growth has been attributed, in specialists opinion,to the integration of online comercialisation and distribution platforms by the companies from the luxury brand sector.Luxury brand executives have been focusing their attention towards online marketing as a branding and selling tool,viewing it as a way for their clients to truly experience the brand and its products,by engaging their customers,improving brand involvement,providing interactivity,which leads to brand loyalty and increased purchase, as well as brand equity growth.

The rise of social media marketing(SMM) and its worldwide usage has driven marketers to seek the opportunities of promoting their brands through a variety of communication channels such as Facebook,Instagram,Twitter,Pinterest.It is noted that the usage of SMM helps raise brand awareness,facilitating communication without any restriction in time place and medium,making it a two way communication between the customer and the brand,creating their own platform in which they exchange ideas,communicate their opinions, share information as well as their experiences with the brand(Kim\&Ko,2012)-articol leveraging a luxury fashion brand.Thus, by engaging in online interaction which leads to creating new content or contributing to content created by others(6,7-articol examining consumer luxury brand related behaviour intention)brands gain exposure and also strengthen relationships with customers, enhancing brand value and,in the case of luxury brands,the prejudices surrounding them(especially that their content availability is limited to the masses) are reduced (Kim\&Ko,2011) Social media has been 
recognized as one of the most powerful marketing tools of the $21^{\text {st }}$ century.According to Emarsys(2019), 3.2 billion users - which equates to about $42 \%$ of the population - log in on social media,spending more than an hour and a half on social platforms every day.

Traditional luxury powerhouses such as Louis Vuitton,Burberry,Gucci are now using digital marketing to target audiences worldwide ,offering them the chance to experience the sophistication ,elegance and luxury,which they embody. Despite the statistic evidence revealing the positive impact of online comercialisation,some luxury brand managers are still hesitant to integrate it into their strategies,questioning if this will negatively impact the brand 's image and its perceived value,hence the characteristics that surround luxury brands are their intangibility,uniqueness, exclusivity.In this paper,our aim is to better understand the luxury brand concept,along with the characteristics that create their image and perceived value and argument the benefits of integrating digital/online marketing into their sales strategies,contributing with our own proposals.

\section{Literature review}

\subsection{The luxury brand concept}

Luxury brands are the most succesful illustration of the power of branding , mainly because their high value emerges from the intangible attributes that lead to the formation of perceptions, image and reputation (Stegeman, 2006, Keller, 2009). In published literature we encounter several definitions proposed for luxury brands. According to Okonkwo (2007), luxury brands have great visibility, distinct identity, global reputation, emotional attractiveness, are innovative, creative, unique, offering premium quality products at premium prices and strict control of distribution. They represent the highest level of prestigious brands that include many physical and psychological values, such as ostentatious value, value of uniqueness, social value, hedonic value and value given by perceived quality (Kim et al., 2009).Their attributes include quality, beauty, sensuality, exclusivity, history, high price, and unicity (Kapferer, 1997) .Dating back to their beginings,luxury brands emerged from the desire to impress other people, associated with the ability to pay high prices and the ostentatious display of wealth (Dubois and Duquesne, 1993).Keller(2009) summarizes their features as following: i) maintaining a premium image; ii) creating intangible associations; iii) quality; (iv) tangible elements such as logos, symbols and packaging design; v) secondary associations with personalities and guarantors; vi) controlled distribution; vii) premium rates; (viii) careful management; ix) legal protection.

The concept of luxury brands arises from their consumers ` perceptions, being determined by personal and interpersonal motives and is strongly influenced by culture (Vigneron \& Johnson, 2004).

\subsection{The dimensions of luxury brands according to consumers` perceptions}

In their published article, "Consumer Rapport to Luxury: Analyzing Complex and Ambivalent Attitudes", Dubois et al. (2001) conducted a study to understand and interpret consumers' attitudes and perceptions of luxury. Six dimensions which we can attribute to luxury brands were obtained upon validation of the results. We will synthesize them, in order to get a better insight of consumer behaviour related to luxury brands,adding some personal observations.

I)Excellent quality:some consumers mentally associate luxury with quality,sometimes in such a strong manner that the two words become synonymous.Consumers have certain expectations when it comes to luxury products,believing that their perceived superior quality guarantees reliability and durability. They trust that the luxury product will not fail to deliver them these qualities. 
II)Very high price:high price is associated with the perception of excellent quality offered by luxury items or services.Thus,some consider that the high price is justified by the superior product quality and the longevity of usage of the luxury product. Also,high pricing is crucial when the brand wants to establish itself as luxurious,because it makes them inaccessible,leaving only a distinct few to be able to indulge in purchashing its products.

III)Scarcity and uniqueness: in consumers 'minds, the high quality of luxury brand products derives from the special characteristics of the components used in the manufacturing and delivery, as well as their unique craftsmanship, which channot be replicated by the mass-producing stores(Dubois et. al,2001).Limited distribution also gives luxury brand consumers a sentiment of fulfillment, that they are part of an elite, and they are the select few who can afford to experience what the luxury brand offers. The idea that luxury products are tailored to their personal taste and requirements, being accessible only to them, gives them a sense of uniqueness. To some,this is the epitome of true luxury,being able to afford items that cater to their specific desires(Dubois et. al,2001).

IV) Aesthetics and polysensuality: consumers expect a multi-sensory experience when purchasing luxury goods;not only the aspect of the product itself has to be appealing,clients want to be drawn by the manner in which the products are presented,to enter a world of beauty(the products look amazing,but also their touch,taste, sense or smell offer unique feelings). A lot of consumers describe purchasing luxury items as a source of hedonistic experience; to them,the feeling of freedom,power,offered by entering the idealistic world of luxury,which is equivalent to the world of the rich and powerful, is a strong incentive when buying luxury branded products.

V)Ancestral heritage and personal history: history and tradition are things which consumers associate with luxury ; for example,when you buy a valuable antique ,you think that it will endure the test of time.Some luxury antiques become more and more valuable over time,making them precious commodities for their owners.Sometimes, the possesors develop personal relationships with them,transforming them into family heirlooms.

VI)Superfluousness: luxury is opposed to necessity;people do not buy luxury branded products because of their functional utility, they buy them for their symbolic features.A luxury is not something you need,it is something additional you can afford.

Luxury is based on the notions of rarity, social recognition and superior quality, consumers buying and consuming luxury brands in search of uniqueness, sensory stimulation, and psychologically gratifying experiences (Frank, 1999, quoted in Ordabayeva et al., 2016 ). In contrast, the digital world is characterized by ubiquity, low costs and the democratization of information, consumers looking for experiences that are common and shared with other peers.

\section{Luxury brands in the digital environment and in social media}

3.1 The reluctancy of luxury brands to use Internet-based strategies

Although online/digital marketing are,presently,an integrated part of building brand equity and have been succesfully implemented in mostly every market sector,luxury firms have been hesitant at embracing the potential of Internet usage in their branding and sales strategy. This reluctancy has been motivated by the challenges faced by luxury companies to maintain the image of their brand,sustain a personal link with their customers.and retain an aura of exclusivity as they simultaneously seek to provide their products and services to increasingly technologically astute customers(Kapferer\&Bastien,2012-).Some marketing specialists believe that if a luxury brand becomes mainstream,this will negatively affect its prestige, as well as the way it is perceived by its customers, failing to deliver the sense of exclusivity,uniqueness and greater social status associated with it,if it becomes accessible to the masses..A remark made by Karl Lagerfeld points out that , " the Internet does not convey the unique feel and sophistication of luxury materials, refined tailoring and extraordinary attention to detail found in luxury fashion".

However,according to recent statistics, not all luxury firms embrace these contradictive opinions and ,instead,were willing to invest in Internet-based technologies,engaging in online 
commerce(D Arpizio,2014).As a result,an increase of profitability was noticed and client interactivity was improved. The millennial generation, who are now into their prime earning years, form the generation that will contribute the most $(130 \%)$ to the luxury market s growth over the next six years,accounting for $50 \%$ of what is forecast to be a $\$ 1,469$ billion market by 2024. According to research by mOONshot digital and McKinsey \& Company, the contribution of online luxury sales to the global high-end market will more than triple by 2025 , reaching $\$ 86$ billion, and accounting for nearly one-fifth of all luxury purchases made. It was also found that at least $80 \%$ of all luxury purchases made today are in some way influenced by consumers' online experience(https://etaileast.wbresearch.com/why-luxury-brands-need-to-embrace-big-data-todrive-growth-strategy-ty-u).

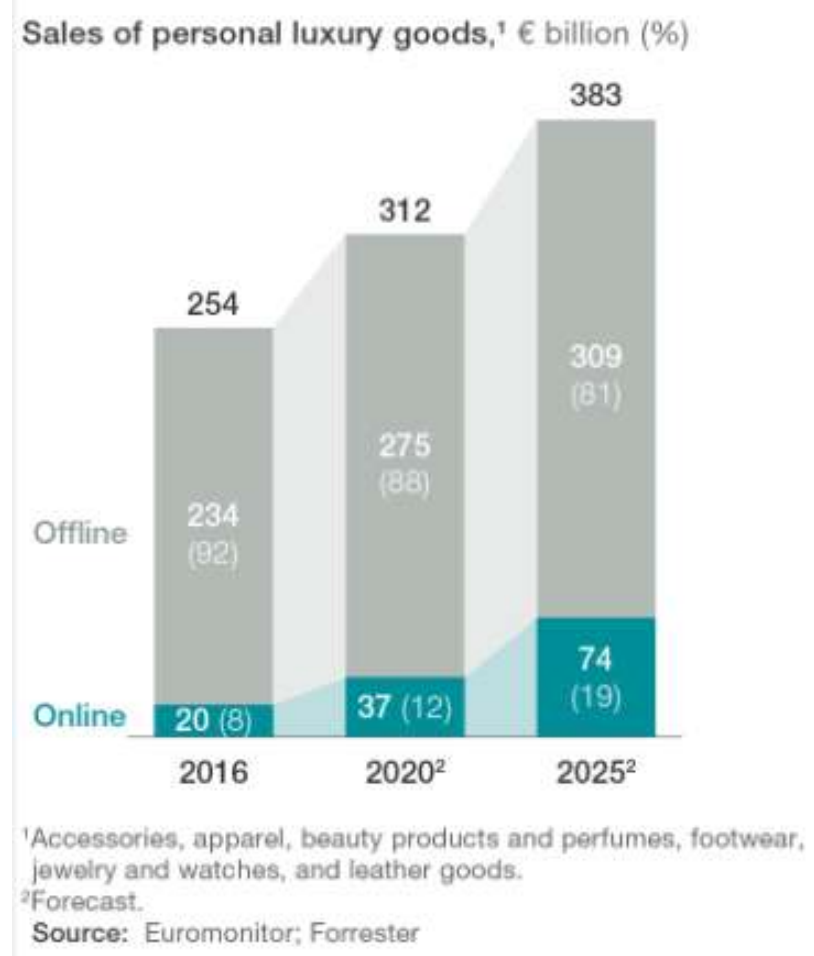

(Image source: mckinsey.com)

Due to the fact that the millenial generation is tech-savvy by definition and much more comfortable with online shopping than its preceeding generations,companies are forced to rethink their traditional marketing strategies in order to appeal to them. The Internet has become a major source of information,allowing consumers to compare prices,read online reviews, exchange ideeas, engaging with the brand and becoming more involved with it.According to Baker et al.(2017),the luxury sector cannot afford to miss the opportunity to benefit from using this important sales channel.Given the fact that the power of luxury brands revolves around the multi-sensory experience they offer,the actual question that comes into the minds of marketers worldwide is:how to succesfully transfer the universe of the luxury brand into the online/digital environment?In the following units,we will analyze different ways to approach these issues.

\subsection{Creating the online luxury experience}

The increasing number of Internet users ,as well as countless possibilities of distribution have companies focusing their attention on the Internet more and more. As the luxury purchasing experience is multi-sensory,so should be the online experience purchasing. Thus,luxury companies are facing the difficult challenge of recreating the magic of their brands into the digital environment. A determining decisional factor for purchasing a luxury product is the atmoshphere created,which cannot be obtained online very easily.A well-known 
fact is that the atmosphere in a traditional shop has a decisive impact on the psychological state of consumers and can influence the decision to purchase a product or not. The in-store act allows customers to engage all their five senses:they can touch fabrics,see the unique product design and the store decorations,smell the new fragrances of newly released perfumes, listen to upbeat music,which is also known to stimulate purchasing due to the feel-good vibe it offers or experience the taste of exquisite champagne,overall,they can indulge in the experience the brand offers them. Moreover,physical contact provided by customer service in traditional shop can play a significant role in purchase decision for many customers.

Hence,companies face the difficult task of finding a way to make the online experience very authentic,to recreate the „magic" of the brand,to capture their attention,for example,when entering the company`s website,appealing to those senses and stimulating them in a limited sensorial surrounding.But we cannot fail to acknowledge the comfort digital environment gives consumers, as well as the freedom of choice. Product comparison, pricing, and switching from one page to another is extremely easy. Visual merchandising is crucial for maintaining existing and potential clients 'interests, in both online and offline retailing.In the online environment, the design of the website can impact a consumers 'decision, wether he will further navigate on the site and even make a purchase .The different components of online environment can cause distinctive emotional reactions that can affect how customers interact with the brand. The time spent on the site, the purchases made, or the subsequent desire to access the site again can be influenced by the stimuli present in the online environment. The components closely related to a site are music, promotions, or other advertisements, user-friendly navigation,pleasing aesthetic design,colors, display of products or other particular features), the promoted product, and the positioning of elements on the web page (Young et al., 2007). The intention to visit a site and the desire to shop online can be influenced by such elements.

According to Okonkwo(2005), the main elements which can be enhanced in the online environment are the visual elements and sound,in order to perfect the online experience.Regarding visual elements a variey of tools can be used to obtain the ultimate „luxmosphere”, These include:high-resolution pictures,unique combinations of colors and styles ,the font style and dimensions in which the text is written,distinct graphics, videos,3D presentations,zoom-in feature for better product view (as a whole or partially),interactive media(ex:chatbox) to facilitate communication with customers,providing them directly with personal assistance,or live catwalk presentations.Sight is the most important sense which traders can use to capture the attention of their potential clients.Sound can be also used to stimulate different reactions in the subconscious of consumers- music genres, tunes, melodic lines- can have differential,emotional impact and can create various moods for online users.Functionality is the essential feature of an online store and defines online experience through easy browsing (userfriendly navigation menu)and interactivity.Luxury brands consumers are aiming for quality services and, at the same time, want their experience to become even more valuable through a high level of interactivity;social media plays a pivotal role in achieving it.

\subsection{The impact of social media on company performance}

As defined by Richter \& Koch(2007),social networks are online applications, platforms and media designed to facilitate interactions, collaborations, and content distribution. They can come in various forms, including weblogs, social blogs, wikis, podcasts, photos, videos, etc. Due to the exponential growth of its users, they are no longer used only by the general public as a means of socialization, business companies and governmental organizations have begun to use them as means of communication,advertising and marketing.

In this way, brands and customers are working together to create new products, services, business models, and values. Meanwhile, brands can gain exposure and strengthen relationships with customers. In the present,social media helps brands and consumers communicate with each other without any time, space, and environmental restrictions, so traditional communication 
channels have been changed to with interactive two-way direct communication. In this way, they work together to create new products, services, business models and values, while brands can gain exposure and improve customer relationships. These activities generated a new term,known as Social Media Marketing(SMM).

\subsection{The effects of social media marketing activities(SMM) of luxury brands}

Recently, luxury brands have turned their attention towards their consumers in their social networks (Kwon et al.,2017). Social media activities can create a comfortable, trustworthy environment for consumers, improving brand involvement, triggering interactivity, increasing loyalty to brand and boosting purchase behaviors(Yu et al.,2017).Social media networks have been used by many brands as two-way communication platforms to reach target audiences in order to stream instant information, as well as to initiate dialogues and interactions (Dimitriu et al.,2014). Thus, the consumer can engage in the online environment of the brand through social networking. Previous research indicates that the most relevant marketing activity for companies is where consumers interact with the brand, generating original content or contributing to content created by other users(Hollebeek et al.2014;King et al.2014).

For example, consumers can comment on brand-related content, evaluate products, or even the brand itself, and engage in interactive actions which help contribute to brand content originally generated by others. These activities usually involve a high or moderate level of brand involvement from consumers, consistent with the positive psychological state induced during an interactive, co-creative consumer experience with brand.This process involves factors such as the level of appeal, the significance and value of the brand to consumers, indicating the relevance of the brand and how it is perceived.Brand involvement is closely linked to the level of engagement of consumers with the brand through social networking (Harrigan et al.,2017). Intangible resources obtained through involvement, such as information transmission, connection, and status may be reasons for consumer brand interaction.Brand involvement has been considered an essential aspect in influencing consumer behavior. Luxury brands have been catalogued as high involvement brands due to the personal nature of the relationship their customers tend to create with them and the psychological motives that determines them to purchase their products. Embracing modern technology and, implicitly, the use of social media networks could not have been bypassed by luxury companies, one of the most powerful and productive business domains.

The use of social media by luxury brands has begun to grow in 2009. Examples include Gucci's luxury brand, which created the 'Guccieyeweb.com' site when launching a collection of glasses for the digital generation Gucci also updates its Facebook page several times a day and is constantly on Twitter. In the same year (2009), Burberry launched an interactive campaign, creating the "Artofthetrench.com" site, which had in the center of attention their iconic trench, considered the house's signature item. This allowed customers to share photos with themselves wearing the Burberry trench in different ways, giving them their "15 minutes of fame" as models on the site, at the same time other consumers could admire their sense of style. the campaign was to admire the trench design and to provide insight into the Burberry brand world.This resulted in the growth of Burberry`s Facebook fan base up to over a million users,considered to be the largest fan count in the luxury sector art the time. An article from Business Today released the following statements:„E-commerce sales grew 50 per cent year-over-year, an increase partially attributed to higher web traffic from the Art of the Trench site and Facebook. The site had 7.5 million views from 150 countries in the first year. Conversion rates from the Art of the Trench click-throughs to the Burberry website were significantly higher than those from other sources.By all metrics, quantitative and qualitative, the campaign was a success." (https://www.businesstoday.in/magazine/lbs-case-study/burberry-social-mediainitiative/story/191422.html). 
Another great example of social media marketing strategy is associating the brand name with a celebrity:given the fact that,nowadays, numerous celebrities actively engage in social media,luxury brands have seen this as an opportunity for their brands to gain exposure through endorsements by well known names from fashion,movie or other such industries. The possible scenarios include photos on social media in which the product is visually present or tagged,live videos in which they mention the product, etc. The association of a brand with a favorite celebrity can influence consumer behavior and increase purchase intention, motivated perhaps by the ilusion of living a similar lifestyle to the ones celebrities have, of owning the same items they own.

Consumers who have close contact with certain brands and their products, will participate in interactive activities related to the brand on social networks. Existing consumerbrand interaction research regarding the role of social media activities of luxury brands in consumer engagement, developing and strengthening consumer relations, as well as interaction (Dessart et al.2015).Integrating consumers into their social media networks provides interdependent effects on customer perception by strengthening interpersonal relationships and interactions, which consequently leads to brand loyalty, intenion of purchase and digital word-ofmouth. (Hudson et al.,2016), state that consumers who have a stronger relationship and emotional attachment through social media interactions are more likely to recommend their favorite brand.

\section{Conclusions}

Despite the tensions between traditional luxury and the digital environment, digital technology can be used to complement, develop and differentiate the experience of luxury brand consumers in physical stores. Numerous authors point out that online social media can be used in marketing activities in the luxury sector ,but complementary to other channels. Social media is an effective communication channel for luxury brands, changing how brand messages are created, distributed and received, transferring power or control into brand image development from marketers to connections and messages created by consumers.

Internet and online distribution deprive the consumer of contact with the seller and the desired goods. On the other hand, the Internet offers a wide variety of products, and surfing on various sites simplifies the purchase. Moreover, products are easy to find on the Internet, eliminating factors such as physical distance or store schedules, and consumers can more easily withstand the temptation to making an impulsive purchase.

From a marketing perspective, more arguments can be identified than counter-arguments in favor of adopting digital marketing, such as additional sales and convenience versus intangibility and conflicts that may occur within the distribution channel. Contradiction of these arguments is applicable to both luxury products and non-luxury products. The Internet is useful to both consumers and companies by its ability to facilitate consumer anticipation. The use of the Internet as a marketing tool offers benefits to both consumers who get the right products (Ansari and Mela, 2003), as well as to companies that are able to achieve a high level of satisfaction and loyalty from their customers and, implicitly, a higher profitability.

\section{References}

Baker, J.;Ashill,N.;N, Amer.;E,Diab(2017).- ,, The internet dillema:An exploratory study of luxury firms 'usage of internet-based technologies", Journal of Retailing and Consumer Services 41(2018)3447.

D Arpizio,C.(2014)- „Luxury Goods Worldwide Market Study”for Bain \& Company (2014), „Luxury Goods Worldwide Market Study Fall-Winter 2014: The rise of the borderless consumer,bttp:// wnw.bain.com/publications/articles/luxury-goods-worldwide-marketstudy-december2014.aspx. 
Dessart, I.;Veloutsou,C.;Thomas, A.-,,Consumer engagement in online brand communities, a social media perspective", J.Prod.Brand Manag.24(2015) 28-42.

Dimitriu,R,;Guesalaga,R.-,Consumers' social media brand behaviors:uncovering underlying motivations and deriving meaningful consumer segments”, „Psybchol.Mark.28(2014)149-165.

Dubois, B. \& Duquesne, P. (1993)-,, The Market for Luxury Goods: Income versus Culturell”, European Journal of Marketing, vol. 27 (1). pp. 35.

Dubois, B., Laurent, G. \& Czellar, S. (2001)-,,Consumer Rapport to Luxury: Analyzing Complex and Ambivalent Attitudes", Working Paper 736, HEC School of Management, Jouy-en-Josas.

Frank, R.H. (1999)-,, Luxury Fever: Why Money Fails to Satisfy in an Era of Excess", New York, NY: Free Press.

Hollebeek,I.D.;Glynn,M.S.;Brodie,R.S.-,,Consumer brand engagement in social media:conceptualization, scale development and vaidation";J.Interact.Mark,28(2014).

Hudson, S,;Huang,I.,Roth,M.S.;Madden,T.J-,,The influence of social media interactions on consumerbrand relationships:a three-country study of brand perceptions and marketing behaviors", Int.J.Res.Mark 33(2016) 27-41.

(https:/ / wnw.businesstoday.in/ magazine/ lbs-case-study/ burberry-social-media-

initiative/story/191422.html).

bttps: / wnw.emarsys.com/ resources/blog/top-5-social-media-predictions-2019/

https: / / etaileast.wbresearch.com/why-luxury-brands-need-to-embrace-big-data-to-drive-growth-strategy-

ty-u.

https:/ / wnw.mckinsey.com/ industries/retail/ our-insights/luxury-in-the-age-of-digital-

darwinism?utm_source=luxe.digitalevutm_campaign=luxe-digital-the-leading-publication-for-

professionals-of-the-luxury-industry.

Harrigan,P.;Evers.U.;Miles,M.;Daly,T.-,,Consumer engagement with tourism social media brands”, Tour.Manag.59(2017)597-609.

Hollebeek,I.D.;Glynn,M.S.;Brodie,R.S.-,,Consumer brand engagement in social media:conceptualization, scale development and vaidation";j.Interact.Mark,28(2014).

Hudson, S,;Huang,I.;Roth,M.S.;Madden,T.J-,,The influence of social media interactions on consumerbrand relationships:a three-country study of brand perceptions and marketing behaviors", Int.J.Res.Mark 33(2016) 27-41.

(bttps:// wnw.businesstoday.in/ magazine/ lbs-case-study/ burberry-social-media-

initiative/story/191422.btml).

bttps: / wnw.emarsys.com/ resources/blog/top-5-social-media-predictions-2019/

https:/ / etaileast.wbresearch.com/why-luxury-brands-need-to-embrace-big-data-to-drive-growth-strategy-

ty-u.

bttps: / / wnw.mckinsey.com/industries/retail/ our-insights/ luxury-in-the-age-of-digital-

darwinism?utm_source=luxe.digitalevutm_campaign=luxe-digital-the-leading-publication-for-

professionals-of-the-luxury-industry.

Kapferer, J.N. (1997)-,, Managing Luxury Brands, Journal of Brand Management”, 251-260.

Kapferer, J.N,Bastien,V.(2012)- „The luxury Strategy:Break the Rules of Marketing to Build Luxury Brands", Kogan Page Publishers

Keller, K.L. (2009)-,, Managing the growth tradeoff: Challenges and opportunities in luxury branding" Journal of Brand Management, 16, pp. 290-301.

Kim ,AJ.(2010)-,, The effects of perceived social media marketing activities on customer equity and purchase intention: focus on luxury fashion brands", Unpublished master's thesis, Yonsei University.

Kim AJ, Ko, E.(2010)-,, Impacts of luxury fashion brand's social media marketing on customer relationship and purchase intention", J Glob Fashion Mark;1(3):164-71.

Kim AJ, Ko E(2010)-,,The impact of design characteristics on brand attitude and purchase intention:focus on luxury fashion brands", J Korean Soc Clothing Text;34(2):252-65.

Kim, A. J., \& Ko, E. (2012)-,, Do social media marketing activities enhance customer equity? An empirical study of luxury fashion brand", Journal of Business Research,65(10), 1480-1486. 
King R.A.; Racherla,P.; Bush,V.D.-,,What we know and don 't know about online word-of-mouth:a review and synthesis of the literature",J.Interact,Mark ,28(2014) 167-183.

Kwon,E.;Ratneshwar,S.;Thorson,E.-,,Consumers' social media advocacy behaviors of luxury brands; an exploratory framework,", J.Interact, Advert.17(2017)13-27.

Kwon,E.;Ratneswar,S.;Thorson,E.-,,Consumers`social media advocacy behaviors of luxury brands:an exploratory framework,J.Interact, Advert.17(2017)13-27.

Okonkwo, U. (2005)-,, Can the Luxury fashion brand store atmosphere be transferred to the Internet?"( bttp:// wmw. brandchannel. com/images/papers/269_Lux_Goods_Online. Pdf,)

Okonkwo, U. (2007)-,, Luxury Fashion Branding: Trends, Tactics, Techniques”, New York: Palgrave Macmillan.

Ordabayeva, N., Cavanaugh, L. A., Dahl, D., Azoulay, A., Coste-Maniere, Jurney, J., Erkehova, D., (2016)-,,Luxury in the Digital World. How Digital Technology Can Complement, Enhance, and Differentiate the Luxury Experience", Wharton University of Pennsylvania, Baker Retailing Center, Report Online Luxury Retailing: Leveraging Digital Opportunities. Research, Industry Practice and Open Questions, 11-15.

Richter A, Koch M. Social software — status quo und Zukunft. Technischer Bericht, 2007-01, Fakultät für Informatik. Universität der Bundeswehr München; 2007.

Stegemann, N. (2006)-,, Unique Brand Extension Challanges for Luxury Brands", Journal of Business \& Economics Research, 4(10). pp.57-68.

Vigneron,F.Johnson,L.W.,2004- „Measuring perceptions of brand luxury,J .Brand Manag.11,484506.

Young, H., Kwon, W.S. \& Lennon S.J. (2007) -, Online visual merchandising (VMD).of apparel web sites", Journal of Fashion Marketing and Management, Vol. 11 Issue:4.

Yu ,U.J.;Cho,E.;Johnson,K.K.P-,,Effects of brand familiarity and brand loyalty on imagery elaboration in online apparel shopping", J.Glob.Fashion Mark.8(2017),193-206. 